\title{
Intellectual Capital dan Keunggulan Kompetitif (Studi Empiris Perusahaan Manufaktur versi Jakarta Stock Industrial Classification- JASICA)
}

\author{
Agnes Utari Widyaningdyah \\ Universitas Katolik Widya Mandala Surabaya dan \\ Mahasiswa Program Doktor Ilmu Ekonomi Universitas Sebelas Maret \\ Y. Anni Aryani \\ Fakultas Ekonomi Universitas Sebelas Maret
}

\begin{abstract}
ABSTRAK
Penelitian ini bertujuan untuk mengetahui apakah terdapat perbedaan penciptaan nilai dan efisiensi kapital intelektual (Intellectual capital atau IC) antara perusahaan dengan keunggulan kompetitif berkelanjutan dan takberkelanjutan. Sampel penelitian adalah perusahaan manufaktur yang terdaftar di Bursa Efek Indonesia versi JASICA selama tahun 2009-2011. Hasil penelitian menunjukkan bahwa terdapat perbedaan signifikan dalam penciptaan nilai atas aset yang diproksikan dengan VAICTM (Value Added Intellectual Coefficient) dan nilai efisiensi IC yang diproksikan dengan ICE (Intellectual Capital Efficiency) antara dua kelompok perusahaan yang diujikan. Hasil penelitian ini mendukung konsistensi teori resource-based yang menyatakan bahwa perusahaan yang dapat mempertahankan keunggulan kompetitifnya mempunyai kemampuan dalam menciptakan nilai tambah bagi stakeholder dan mengelola aset stratejiknya yang bersifat VRIN (Valuable, Rare, Inimitable, and Non-substitutable) dengan efisien.
\end{abstract}

Kata kunci: Kapital intelektual (intellectual capital), keunggulan kompetitif, teori resourcebased.

\begin{abstract}
This research investigates the differences on value added and intellectual capital (IC) efficiency of the companies with sustained and un-sustained competitive advantage. This research uses manufacturing companies listed on Indonesia Stock Exchange during 20092011 according to JASICA version. This research indicates that the value creation (proxied by value added intellectual coefficient-VAICTM) and IC efficiency (proxied by intellectual capital efficiency-ICE) of companies with sustained competitive advantage significantly different from companies with unsustained competitive advantage. This finding supports the Resource-based Theory which asserts that company with sustained competitive advantage has an ability to create value for its stakeholder and manages its VRIN (Valuable, Rare, Inimitable, and Nonsubstitutable) strategic assets efficiently.
\end{abstract}

Keywords: Intellectual capital, competitive advantage, resource-based theory.

\section{PENDAHULUAN}

Era informasi dan pengetahuan telah mengubah lingkungan bisnis menjadi semakin kompetitif. Fokus pengembangan bisnis tidak lagi bertumpu pada mesin-mesin industri melainkan pada kemampuan sumber daya manusia untuk terus melakukan inovasi. Peran sumber daya yang bersifat takberwujud (aset takberwujud) menjadi lebih dominan dibandingkan sumber daya berwujud. Hal ini kemudian berkembang menjadi topik penelitian dalam ranah akuntansi (Bozollan, et al. 2006, Singh and Zahn 2008, Skinner 2008), yang kemudian mempertanyakan relevansi dan reliabilitas dari laporan keuangan yang merupakan sarana pelaporan atas aset perusahaan (Lev and Zarowin 1999, Roslender and Fincham 2001). 
Beberapa penelitian menunjukkan adanya kesenjangan antara nilai pasar dan nilai buku perusahaan (Shiu 2006, Cheng, et al. 2010, Guthrie, et al. 2012). Hal tersebut diduga adanya nilai yang tidak dilaporkan dalam laporan keuangan namun mendapat perhatian lebih dari investor. Nilai item yang tidak tercantum tersebut kemudian banyak dikenal dengan istilah intellecttual capital (IC). Secara umum, IC terbagi menjadi 3 komponen utama, yaitu kapital manusia (human capital), kapital struktural/organisasional/internal, dan kapital relasional/eksternal (Bontis 1998, Bontis et al. 2000, Petty and Guthrie 2000).

Fenomena keberadaan IC dapat dipahami dalam sebuah rerangka teori yang dikenal sebagai teori berbasis sumber daya atau resource-based theory (RBT) yang dikembangkan oleh Barney (1991). Teori ini menyatakan bahwa sumber daya yang bersifat bernilai (valuable), langka (rare), tidak dapat ditiru (inimitable), dan taktergantikan (non-substitutable) atau disingkat VRIN menjadi aset stratejik yang berkontribusi dalam menciptakan keunggulan kompetitif (competitive advantage) (Barney and Clark 2007). Menurut Cheng, et al. (2010) IC merupakan sumber daya kunci dan penggerak (driver) atas kinerja serta penciptaan nilai perusahaan, sehingga IC berperan penting dalam menciptakan maupun mempertahankan keunggulan kompetitif. Dalam rerangka RBT, IC berkontribusi dalam meningkatkan keunggulan kompetitif melalui penciptaan nilai dari sumber daya dan kapabilitas yang unik. Semakin efisien perusahaan dalam mengelola IC, maka akan semakin cepat tercipta keunggulan kompetitif (Firer and Williams 2003, Shiu 2006, Coudhury 2010, Khani, et al. 2011).

Menurut Lin dan Huang (2011) terdapat perbedaan nilai pasar antara perusahaan yang berorientasi pada light assets (dalam hal ini IC) dengan perusahaan yang berorientasi pada hard atau physical assets pada industri yang sama. Investor memberikan perhatian lebih yang ditandai dengan tingginya nilai pasar pada perusahaan dengan inputan IC yang lebih besar. Hasil ini didukung dengan penelitian Kamukama et al. (2011) yang menyatakan bahwa IC berkorelasi dengan keunggulan kompetitif pada industri keuangan mikro di Uganda.

Pentingnya peranan IC dalam praktik bisnis di Indonesia telah mendapat perhatian serius dengan diselenggarakannya ajang MAKE$^{1}$ (Most

\footnotetext{
1 Sebuah ajang penghargaan yang diselenggarakan oleh The KNOW Network yaitu organisasi yang melakukan program riset untuk perusahaan yang menitikberatkan strategi knowledge dalam melakukan kompetisi bisnisnya. Di Indonesia MAKE Awards diselenggarakan sejak tahun 2005 berdasarkan hasil riset yang dilakukan oleh Dunamis Organization of Services.
}

Admired Knowledge Enterprise) Awards setiap tahun sejak tahun 2005. Para finalis MAKE Indonesia bahkan beberapa kali telah menjuarai MAKE Asia. Hal ini dapat menjadi indikasi kesadaran perusahaan-perusahaan di Indonesia dalam mengelola IC sebagai sumber daya stratejik.

Pentingnya peranan IC dalam mewujudkan keunggulan kompetitif dan tumbuhnya kesadaran perusahaan-perusahaan di Indonesia dalam mengelola IC merupakan alasan pentingnya penelitian ini dilakukan. Kontribusi IC dalam menciptakan keunggulan kompetitif di Indonesia belum dieksplorasi lebih lanjut, terutama bagaimana perusahaan yang mampu mengelola IC dengan baik dapat mempertahankan keunggulan kompetitifnya. Selama ini, sebagian besar penelitian IC di Indonesia mengaitkan IC dengan kinerja (Margaretha dan Rahman 2006; Suwarno 2011) maupun dengan praktik pengungkapan laporan keuangan (Suhardjanto dan Wardhani 2010, Ullum 2011). Berdasarkan argumentasi tersebut maka yang menjadi permasalahan dalam penelitian ini adalah: "Apakah terdapat perbedaan efisiensi pengelolaan IC antara perusahaan yang mempunyai keunggulan kompetitif berkelanjutan (sustained competitive advantage) dengan perusahaan yang tidak mempunyai keunggulan kompetitif takberkelanjutan (unsustained competetive advantage)." Selain untuk mengetahui perbedaan efisiensi pengelolaan IC, penelitian ini juga bertujuan untuk menguji konsistensi teori RBT yang menyatakan bahwa sumber daya yang bersifat VRIN dapat berkontribusi pada keunggulan kompetitif.

\section{Resource-based Theory (RBT)}

Teori berbasis sumber daya (RBT) merupakan pengembangan lanjutan atas teori Ricardo's Economic Rent, dan structure-performance-conduct Porter (Barney and Clark 2007). Teori ini muncul karena adanya pertanyaan stratejik tentang mengapa sebuah perusahaan dapat mengungguli perusahaan lain dan mempunyai kinerja superior yang berkelanjutan (sustainable superior performance). Perusahaan yang membangun sumber dayanya sendiri dan dapat mengendalikannya akan mempunyai kemampuan mempertahankan keunggulannya dibandingkan jika perusahaan membeli atau memperoleh sumber dayanya dari luar organisasi. Kumpulan sumber daya yang unik yang dimiliki dan dikendalikan perusahaan memungkinkan perusahaan untuk mencapai dan mempertahankan kinerja superior yang berkelanjutan. 
Sumber daya unik yang dimaksudkan dalam RBT adalah sumber daya yang mempunyai sifat bermanfaat/bernilai (valuable), langka (rare), tidak dapat ditiru (inimitable), dan tidak terganti (nonsubtitutable). Bernilai artinya dapat digunakan untuk aktivitas perusahaan, langka berarti hanya dimiliki oleh sedikit perusahaan saja. Tidak dapat ditiru berarti sumber daya tersebut dilindungi dari kemungkinan ditiru oleh pesaing. Tidak terganti artinya sumber daya hanya dimiliki oleh perusahaan tertentu saja dan tidak dapat diganti dengan produk lain (Barney, et al. 2001). Jenis sumber daya ini dapat mengantarkan perusahaan pada pencapaian keunggulan kompetitif.

Perkembangan RBT cukup pesat, terutama dalam pembuktian konsistensinya dengan menggunakan studi empiris di berbagai ranah ilmu. Ranah yang pertama kali mengembangkannya adalah manajemen stratejik (Spanos and lioukas 2001, Schroeder et al. 2002, Ray, et al. 2004), yang kemudian berkembang pada ranah ilmu yang lain, seperti manajemen sumber daya manusia (Gates and Langevin 2012; Connelly, et al. 2012), serta Akuntansi (Henri 2006, Toms 2010).

\section{Intellectual Capital (IC)}

Pada dasarnya belum ada definisi yang mantap terkait dengan konsep IC. Beberapa peneliti memberikan definisi yang berbeda yang kemudian berdampak pada pembagian komponen atau taksonomi IC (Brooking 1997, Roos and Roos 1997, Bontis 1998, 1999, Pulic 2000, Petty and Guthrie 2000). Terdapat dua definsi IC yang menjadi rujukan penelitian ini dikarenakan kemampuannya dalam mengoperasionalisasikan variabel IC, yaitu definsi IC menurut OECD (Organisation for Economic Cooperation and Development) dan Pulic. Menurut OECD, IC didefinsikan sebagai (Petty and Gutrie 2000:158):

"the economic value of two categories of intangible assets of a company: (1) organisational ("structural") capital; and (2) human capital."

Definisi IC menurut Pulic adalah (Andriessen 2004: 365):

"Intellectual capital consists of human and structural capital.”

Kedua definisi di atas menyatakan bahwa komponen IC terdiri atas kapital manusia (human capital selanjutnya disingkat HC) dan kapital struktural (structural capital selanjutnya disingkat SC). Jantung dari IC adalah HC, yang didefinisikan sebagai kombinasi atas pengetahuan, keahlian, inovasi, dan kecakapan (ability) karyawan, sedangkan SC merujuk pada proses maupun prosedur yang dibentuk maupun disimpan melalui sistem informasi perusahaan yang mempercepat mengalirnya pengetahuan ke seluruh organisasi (Bontis, Keow, Richardson, 2000).

Selain komponen HC dan SC, Pulic (2010, 2004) menambahkan komponen kapital fisis dan finansial (capital employed, selanjutnya disingkat CE) sebagai penunjang IC dalam memberikan nilai tambah bagi perusahaan. Komponen HC dan SC tidak dapat bekerja dalam memberikan nilai tambah apabila tidak didukung oleh CE, sehingga efisiensi pengelolaan IC dapat diukur dengan sinergi yang terjadi diantara ketiga komponen tersebut, yaitu HC, SC, dan CE. Berikut adalah pembagian komponen IC menurut Pulic (2000):
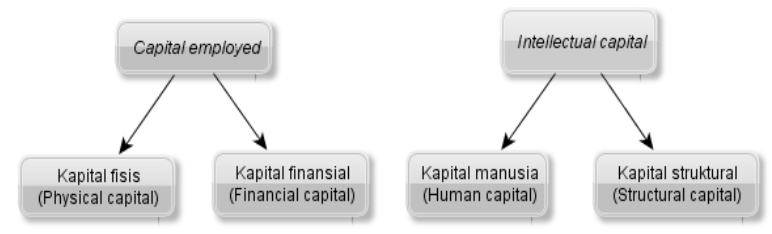

Sumber: Pulic (2000)

\section{Gambar 1. Jenis Kapital Menurut Pulic}

\section{Keunggulan Kompetitif}

Sebuah perusahaan dikatakan mempunyai keunggulan kompetitif apabila dapat menciptakan nilai ekonomis yang lebih tinggi dibandingkan perusahaan lain dalam industrinya. Namun lebih lanjut dikatakan hal yang paling penting adalah menjaga keberlanjutan dari keunggulan kompetitif tersebut atau yang biasa disebut sebagai sustained competitive advantage (Barney and Clark 2007). Keunggulan kompetitif dalam RBT merupakan penciptaan abnormal profit (Peteraf 1993) atau tingkat kembalian di atas rata-rata (above average returns) dengan memanfaatkan fitur-fitur khusus yang dimiliki perusahaan (Lin and Huang 2011).

Keunggulan kompetitif dapat dibedakan menjadi 2, yaitu keunggulan kompetitif berbasis logistik (Porter 1985) dan keunggulan kompetitif berbasis sumber daya (Barney 1991). Penelitian ini menggunakan pendekatan yang kedua yaitu keunggulan kompetitif yang berbasis sumber daya sebagaimana diuraikan dalam RBT.

\section{Skema Konseptual}

Skema konseptual penelitian ini adalah sebagai berikut:

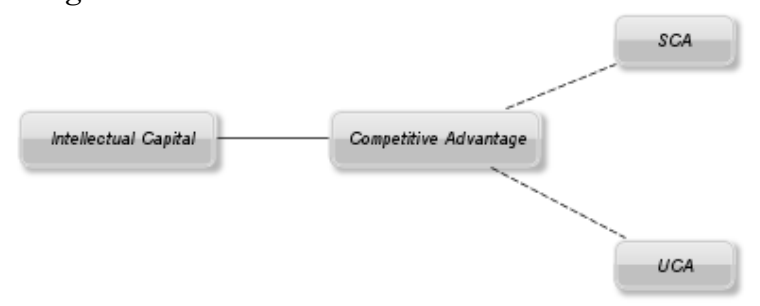

Gambar 2. Skema Konseptual Penelitian 
Keterangan:

SCA: sustained competitive advantage (kelompok perusahaan yang mempunyai keunggulan kompetitif berkelanjutan).

UCA: unsustained competitive advantage (kelompok perusahaan yang mempunyai keunggulan kompetitif namun takberkelanjutan).

Penelitian ini bertujuan untuk mengetahui apakah terdapat perbedaan efisiensi pengelolaan IC pada kelompok perusahaan yang mempunyai keunggulan kompetitif berkelanjutan dengan kelompok perusahaan yang mempunyai keunggulan kompetitif namun takberkelanjutan. Sebagaimana dinyatakan dalam RBT bahwa sumber daya stratejik dapat berkontribusi dalam menciptakan keunggulan kompetitif (Barney and Clark 2007) dan menempatkan perusahaan pada posisi yang menguntungkan dalam persaingan, maka terdapat adanya dugaan perbedaan nilai efisiensi IC pada dua kelompok perusahaan yang akan diteliti.

Efisiensi IC dalam penelitian ini menggunakan proksi value added intellectual coefficient (VAICTM) yang dikembangkan oleh Pulic (2004, 2010). Pertimbangan pemilihan proksi tersebut selain selaras dengan tujuan penelitian; yakni mencari hubungan antara IC dengan keunggulan kompetitif yang ditandai dengan kemampuan perusahaan mengelola IC secara efisien; data yang digunakan dalam penghitungan VAICTM dapat diakses dengan mudah oleh publik dan terjamin validitasnya karena telah diaudit.

Perusahaan yang mempunyai keunggulan kompetitif berkelanjutan mengelola IC secara efisien dikarenakan IC merupakan sumber inovasi yang dapat digunakan sebagai alat memenangkan persaingan. Penelitian Tang and Liou (2010) menunjukkan adanya nilai optimal rasio-rasio efisiensi operasional, yang mencakup proksi atas hubungan dengan pelanggan, pemasok, inovasi, maupun pengelolaan aset tetap. Kapital intelektual (IC) merupakan aset stratejik perusahaan dan berfungsi sebagai driver atas kinerja, dengan demikian dapat dikatakan bahwa pengelolaan IC secara efisien akan berkontribusi pada kinerja superior yang merupakan indikator atas keunggulan kompetitif berkelanjutan (Pulic 2004, 2010).

\section{Pengembangan Hipotesis}

Kapital intelektual (IC) merupakan sumber daya kunci yang berperan aktif dalam penciptaan nilai perusahaan, sehingga IC berperan penting dalam menciptakan maupun mempertahankan keunggulan kompetitif. Dalam rerangka RBT, IC berkontribusi dalam meningkatkan keunggulan kompetitif melalui penciptaan nilai dari sumber daya dan kapabilitas yang unik (Cheng, et al. 2010). Semakin efisien perusahaan dalam mengelola IC, maka akan semakin cepat tercipta keunggulan kompetitif (Firer and Williams 2003, Shiu, 2006, Coudhury 2010, Khani, et al. 2011).

Perusahaan yang mampu melakukan inovasi secara terus-menerus melalui pembelajaran (learning) dapat beradaptasi terhadap lingkungan bisnis yang dinamis (Bisbe dan Otley, 2004). IC merupakan kapital utama terbentuknya inovasi dan pembelajaran sehingga perusahaan mampu terus bertahan dalam kompetisi bisnis yang tinggi. Dengan demikian, IC tidak hanya dibutuhkan perusahaan untuk bertahan (survive/sustain) tetapi juga mampu untuk mencapai kinerja yang superior (Barney dan Clark, 2007; Dunamis, 2013).

Beberapa penelitian menunjukkan adanya perbedaan pengelolaan IC akan berpengaruh terhadap kinerja maupun kemampuan perusahaan dalam mempertahankan bisnisnya. Penelitian Roberts (1999) membuktikan bahwa perusahaan yang mempunyai kemampuan inovasi yang didukung dengan intensitas IC yang tinggi mempunyai kemampuan mempertahankan profitabilitas yang tinggi secara persisten (sustained high profitability) dibandingkan dengan perusahaan yang tidak mempunyai intensitas IC yang tinggi. Penelitian Tang and Liou (2010) menunjukkan nilai rasio-rasio kemampuan mengelola aset takberwujud perusahaan dengan keunggulan kompetitif lebih tinggi dibandingkan perusahaan dengan kerugian bersaing (competitive disadvantage). Hal ini menunjukkan bahwa kemampuan dalam mengelola pengetahuan serta hubungan yang baik dengan pelanggan maupun pemasok berhubungan positif dengan kemampuan perusahaan dalam mempertahankan keunggulan kompetitifnya. Demikian halnya dengan penelitian Lin and Huang (2011) yang menunjukkan adanya perbedaan nilai abnormal return pada perusahaan yang mempunyai inputan aset takberwujud yang tinggi dibandingkan dengan perusahaan dengan inputan aset fisik yang tinggi.

Berdasarkan uraian tersebut, maka dapat dirumuskan hipotesis sebagai berikut:

H1: Terdapat perbedaan signifikan nilai efisiensi organisasi (VAICTM) antara kelompok perusahaan yang memiliki keunggulan kompetitif berkelanjutan/sustained competitive advantage (SCA) dengan kelompok perusahaan yang memiliki keunggulan kompetitif takberkelanjutan/unsustained competitive advantage (UCA).

Komponen sentral IC, yaitu human capital yang mencakup kemampuan keahlian, maupun pengalaman karyawan akan memberikan karak- 
ter yang berbeda bagi perusahaan (Bontis 1998) dan bahkan OECD menyebutnya sebagai penggerak aktivitas ekonomi (economic driver activity), persaingan, dan kemakmuran perusahaan (Kamukama, et al. 2011). Teori sumber daya manusia menyatakan bahwa kemampuan individu akan meningkatkan kemampuan kognitif yang mengarah pada aktivitas produktif dan efisien.

Kapital struktural (structural capital) yang merupakan hasil interaksi karyawan dengan perusahaan atau stock of knowledge yang dimiliki perusahaan dapat menjadikan perusahaan bertahan dalam lingkungan kompetitif. Kemampuan perusahaan untuk mengelola teknologi yang memungkinkan aliran pengetahuan menyebar ke seluruh organisasi menjadikan organisasi tersebut unggul dalam pengelolaan informasi (Widener 2006).

Selain efisiensi pengelolaan $\mathrm{IC}^{2}$, perusahaan juga diharapkan mampu memanfaatkan kapital fisis maupun keuangan yang dimilikinya sehingga akan tercipta daya saing yang kuat (Pulic 2010). Interelasi komponen IC yang berkualitas akan membawa perusahaan pada posisi yang menguntungkan dalam lingkungan persaingan bisnis (Bontis 1998).

Berdasarkan uraian tersebut, maka dapat dirumuskan hipotesis sebagai berikut:

H2a : Terdapat perbedaan signifikan nilai efisiensi kapital manusia/sumber daya manusia (HCE) antara kelompok perusahaan yang memiliki keunggulan kompetitif berkelanjutan/sustained competitive advantage (SCA) dengan kelompok perusahaan yang memiliki keunggulan kompetitif takberkelanjutan/unsustained competitive advantage (UCA).

$\mathrm{H} 2 \mathrm{~b}$ : Terdapat perbedaan signifikan nilai efisiensi kapital struktural (SCE) antara kelompok perusahaan yang memiliki keunggulan kompetitif berkelanjutan/sustained competitive advantage (SCA) dengan kelompok perusahaan yang memiliki keunggulan kompetitif takberkelanjutan/ unsustained competitive advantage (UCA).

H2C: Terdapat perbedaan signifikan nilai efisiensi kapital intelektual (ICE) antara kelompok perusahaan yang memiliki keunggulan kompetitif berkelanjutan/sustained competetive advantage (SCA) dengan kelompok perusahaan yang memiliki keunggulan kompetitif takberkelanjutan/unsustained competetive advantage (UCA).

\footnotetext{
2 Menurut Pulic (2004) nilai efisiensi IC merupakan kombinasi atas efisiensi HC dan SC. Nilai tambah akan tercipta apabila terdapat sinergi antara $\mathrm{HC}, \mathrm{SC}$, dan $\mathrm{CE}$ atau IC dan CE.
}

H2d : Terdapat perbedaan signifikan nilai efisiensi kapital fisis dan keuangan (CEE) antara kelompok perusahaan yang memiliki keunggulan kompetitif berkelanjutan/sustained competitive advantage (SCA) dengan kelompok perusahaan yang memiliki keunggulan kompetitif takberkelanjutan/unsustained competitive advantage (UCA).

\section{METODE PENELITIAN}

\section{Sampel Penelitian}

Populasi penelitian ini adalah semua perusahaan manufaktur (secondary sectors) yang terdaftar di Bursa Efek Indonesia pada tahun 2009-2011. Metode sampling yang digunakan adalah purposive sampling dengan kriteria sebagai berikut:

1. Termasuk dalam secondary sectors versi JASICA (Jakarta Stock Industrial Clasification) dengan kode sektor 4 dan 5. Kriteria sampel ini dimaksudkan karena beberapa subsektor dalam sektor 4 (aneka industri/miscellaneous industry) dan sektor 5 (industri barang konsumen/consumer goods industry) mempunyai kriteria sebagai industri sarat pengetahuan (knowledge-intensive industry) menurut OECD (Organization for Economic Cooperation and development); yaitu:

a. Kode 41 (machinery and heavy equipment)

b. Kode 42 (automotive and components)

c. Kode 46 (electronics)

d. Kode 53 (pharmaceuticals)

e. Kode 54 (cosmetics and households)

2. Terdaftar (listing) sejak tahun 2009-2011 serta tidak delisting pada tahun tersebut. Pertimbangan pengambilan tahun penelitian adalah 3 tahun terbaru laporan keuangan diterbitkan, selain itu 3 tahun mewakili lebih penghitungan kinerja dan keunggulan kompetitif minimal seperti yang dinyatakan oleh Spanos and Lioukas (2001) serta Tang and Liou (2010).

3. Menerbitkan laporan keuangan pada tahun pengamatan dan memiliki data yang dibutuhkan untuk penelitian ini.

\section{Definsi Operasional dan Pengukuran Variabel}

\section{Intellectual Capital (IC)}

Variabel IC merujuk pada nilai efisiensi pengelolaan IC sebagaimana dinyatakan oleh Pulic (2004). Pengukuran efisiensi IC dengan menggunakan value added intellectual capital (VAICTM) dengan langkah-langkah sebagai berikut: 
1) Menghitung nilai tambah yang diformulasikan sebagai berikut:

$V A=G M-S g a \operatorname{Exp} .+L E x p$

Keterangan:

VA : Nilai tambah (value added)

GM : Laba kotor (gross margin)

SgaExp. : Biaya penjualan, umum, dan administrasi (selling, general, and administration expenses)

LExp. : Biaya tenaga kerja yang merupakan jumlah biaya gaji dan upah karyawan (labor expenses)

2) Langkah berikutnya adalah menghitung nilai kapital manusia (human capital/HC), kapital struktural (SC), dan capital employed (CE).

$H C=$ LExp

$S C=V A-H C$

$C E=$ capital fisis + capital financial

$=$ total asset - asset tak takberwujud

$I C=H C+S C$

Nilai kapital manusia ditunjukkan oleh biaya upah dan gaji tenaga kerja. Kapital struktural merupakan selisih dari nilai tambah dengan kapital manusia, hal ini selaras dengan persamaan bahwa IC merupakan kumpulan dari kapital struktural dan manusia. Capital employed merupakan proksi atas aset berwujud (tangible assets) sehingga diformulasikan sebagai selisih antara total aset dan aset takberwujud (Cheng, et al. 2005).

3) Menghitung rasio efisiensi masing-masing kapital. Pada dasarnya VAIC merupakan jumlah dari 3 indikator terpisah (Firer and Williams 2003), yaitu:

(a) Efisiensi kapital/sumber daya yang digunakan (capital employed efficiency)/CEE yang merupakan nilai tambah (value added/VA) dari kapital yang digunakan dalam operasional perusahaan.

(b) Efisiensi sumber daya manusia yang digunakan (human capital efficiency)/HCE yang merupakan VA dari sumber daya manusia yang digunakan dalam operasional perusahaan.

(c) Efisiensi sumber daya struktural yang digunakan (structural capital efficiency)/SCE yang merupakan VA dari sumber daya struktural yang digunakan dalam operasional perusahaan.

(d) Efisiensi sumber daya intelektual yang digunakan (intellectual capital efficiency)/ICE yang merupakan VA dari sumber daya intelektual yang digunakan dalam operasional perusahaan.

Atau dalam bentuk matematis menjadi:

$V A I C^{T M}=H C E+S C E+C E E$ atau

$V A I C^{T M}=I C E+C E E$

Keterangan:

VAIC: VA intellectual coefficient perusahaan

CEE : VA/CE, capital employed efficiency perusahaan

HCE : VA/HC, human capital efficiency perusahaan

SCE : SC/VA, structural capital efficiency perusahaan

ICE : VA/IC, intellectual capital efficiency perusahaan

\section{Keunggulan Kompetitif}

Sumber keunggulan kompetitif menurut Tang and Liou (2010) dibagi menjadi 4, yaitu hubungan dengan pelanggan (customer relationship), hubungan dengan pemasok (supplier relationship), kekayaan intelektual (intellectual property), dan pengelolaan aset tetap (fixed asset management). Hubungan dengan pelanggan diproksikan dengan rasio biaya iklan dan promosi dengan total penjualan, serta perputaran piutang. Hubungan dengan pemasok diukur dengan menggunakan perputaran piutang dan persediaan, serta rasio antara harga pokok produksi dengan total penjualan. Kekayaan intelektual diukur dengan menggunakan rasio biaya penjualan, umum dan administrasi terhadap total penjualan, sedangkan pengelolaan aset etap diukur dengan menggunakan rasio biaya depresiasi terhadap total penjualan, serta perputaran aset tetap.

Lebih lanjut Tang dan Liou (2010) membuktikan secara matematis bahwa kombinasi rasio-rasio yang merupakan proksi dari hubungan dengan pelanggan, pemasok, proksi kekayaan intelektual, dan pengelolaan aset tetap tersebut akan membentuk sebuah rasio baru yang dinamakan sebagai DuPont Identity atau dikenal dengan istilah ROIC (Return on Invested Capital). Formulasi ROIC dapat dihitung sebagai berikut:

ROIC $=\frac{\text { NOPLAT }}{S} X \frac{S}{I C}$

$=\frac{(S-C G S-A d v-R \& D-D e p-S G \& A-\operatorname{tax}) / S}{(F A+A R+I n v-A P+\text { cash }) / S}$

Keterangan:

ROIC : return on invested capital

NOPLAT: net operating income less adjusted tax (atau ekuivalen dengan laba bersih setelah pajak)

IC : invested capital (kapital/aset yang diinvestasikan)

$\mathrm{S} \quad$ : sales (penjualan)

CGS : cost of goods sold (harga pokok penjualan) 


$\begin{array}{lll}\text { Adv } & : & \begin{array}{l}\text { advertising expenses (biaya iklan dan } \\ \text { promosi) }\end{array} \\ \text { R\&D } & : & \begin{array}{l}\text { research and development expenditure } \\ \text { (beban yang dikeluarkan untuk riset }\end{array} \\ & & \text { dan pengembangan) } \\ \text { Dep } & : & \text { depreciation expenses (biaya penyu- } \\ & \text { sutan) } \\ \text { SG\&A } \quad: & \text { selling, general, and administration } \\ & & \text { expenses (beban umum dan adminis- } \\ & & \text { trasi) } \\ \text { Tax } & : & \text { tax (biaya pajak) } \\ \text { FA } & : & \text { fixed assets (aktiva tetap) } \\ \text { AR } & : & \text { account receivable (piutang usaha) } \\ \text { Inv } & : & \text { inventory (persediaan) } \\ \text { AP } & : & \text { account payable (utang usaha) } \\ \text { cash } & : & \text { cash (kas dan setara kas) }\end{array}$

\section{Teknik Pengumpulan Data}

Data yang digunakan dalam penelitian ini merupakan data sekunder berupa laporan keuangan tahunan yang diambil dari Bursa Efek Indonesia (BEI) melalui situs www.idx.com. Beberapa laporan keuangan tahunan yang tidak dapat diunduh melalui situs BEI, diperoleh langsung dengan mengunduh dari situs perusahaan yang bersangkutan.

\section{Alat Analisis Statistik}

Alat analisis statistik yang digunakan adalah analisis komparasi dengan menggunakan uji $\mathrm{T}$ sampel bebas (independent samples t-test) dikarenakan data yang diujikan berskala rasio untuk dua sampel yang independen. Pengujian statistik penelitian ini menggunakan bantuan perangkat lunak SPSS 17.0. Urutan pengujian adalah sebagai berikut:

1) Pembagian sampel ke dalam kelompok perusahaan dengan keunggulan kompetitif berkelanjutan (sustained competitive advantage/ SCA) dan kelompok perusahan dengan keunggulan kompetitif takberkelanjutan (unsustained competitive advantage/UCA). Kriteria yang digunakan adalah dengan menghitung ROIC masing-masing perusahaan, dan hanya perusahaan yang mempunyai rata-rata ROIC di atas rata-rata ROIC industrinya selama 3 tahun berturut-turut yang dikatakan memiliki keunggulan kompetitif berkelanjutan yang bisa diobservasi. Kriteria ini mengacu pada penelitian yang dilakukan oleh Spanos and Lioukas (2001) serta Tang and Liou (2010).

2) Pengujian $t$ sampel bebas (independen samples t-test)
Sebelum melakukan uji t sampel bebas, maka diperlukan uji homogenitas/uji F/uji Levene's. Uji ini dilakukan untuk melihat apakah terdapat varian yang sama untuk setiap kelompok data. Apabila varian sama, maka uji t menggunakan nilai 'Equal Variance Assumed' (diasumsikan varian sama), dan jika varian berbeda menggunakan nilai 'Equal Variance not Assumed' (diasumsikan varian berbeda). Kriteria pengujian menggunakan signifikansi dengan $\alpha=5 \%$.

\section{HASIL PENELITIAN DAN PEMBAHASAN}

\section{Deskripsi Obyek Penelitian}

Berdasarkan kriteria pengambilan sampel sebagaimana telah diuraikan sebelumnya, maka diperoleh sampel seperti pada Tabel 1.

\section{Tabel 1. Penentuan Sampel}

\begin{tabular}{lc}
\hline Kriteria & Jumlah \\
\hline 1. Secondary sector JASICA & 136 \\
2. Sektor 3 & $(63)$ \\
3. Delisting & $(1)$ \\
4. Menggunakan mata uang asing & $(4)$ \\
5. Data tidak lengkap & $(3)$ \\
6. Listing tidak berturut-turut & $(4)$ \\
\hline Jumlah sampel akhir & $\mathbf{6 1}$ \\
Jumlah observasi & $\mathbf{1 8 3}$ \\
\hline
\end{tabular}

Sumber: Bursa Efek Indonesia melalui IDX (2013)

Jumlah sampel akhir yang akan dianalisis adalah 61 perusahaan selama 3 tahun berturutturut, dengan demikian jumlah observasi adalah 183 observasi. Dari 61 perusahaan, 30 perusahaan berada pada sektor 4 (aneka industri/miscellaneous industry) dan sisanya sebanyak 31 perusahaan pada sektor 5 (industri barang konsumen/consumer goods industry).

\section{Pembagian Sampel ke dalam Kelompok SCA dan UCA}

Hasil pengolahan data berdasarkan kriteria yang telah diuraikan sebelumnya, diperoleh 24 perusahaan masuk dalam kriteria SCA dan 37 perusahaan masuk kriteria UCA. Dari 24 perusahaan SCA, sebanyak 7 perusahaan (29\%) didominasi perusahaan dari sektor 5 sub sektor 1 (makanan dan minuman/food and beverages), sedangkan pada kelompok UCA, sebanyak 12 perusahaan (32\%) didominasi perusahaan sektor 4 sub sektor 3 (tekstil dan garmen). Berikut deskripsi dari kedua kelompok sampel (seperti pada Tabel 2). 
Tabel 2. Deskripsi Sektor Sub Sampel

\begin{tabular}{ccccc}
\hline Sektor & $\begin{array}{c}\text { Sub } \\
\text { Sektor }\end{array}$ & Keterangan & SCA & UCA \\
\hline \multirow{4}{*}{4} & 1 & Mesin-mesin dan alat & 0 & 0 \\
& & berat & & \\
& 2 & Otomotif & 4 & 4 \\
& 3 & Tekstil dan garmen & 2 & 12 \\
& 4 & Sepatu & 1 & 2 \\
& 5 & Kabel & 3 & 2 \\
& 6 & Elektronik & 0 & 1 \\
\hline \multirow{4}{*}{} & & Sub Total & $\mathbf{1 0}$ & $\mathbf{2 1}$ \\
\hline & 1 & Makanan dan & 7 & 5 \\
& 2 & minuman & & \\
& 2 & Industri rokok & 1 & 1 \\
& 3 & Farmasi & 4 & 6 \\
& 4 & Kosmetik & 1 & 2 \\
& 5 & Peralatan rumah & 1 & 2 \\
& tangga & & \\
\hline
\end{tabular}

Sumber: Data Sekunder JASICA (2012)

Keterangan:

Sektor 4 : Aneka Industri (Miscellanous Industry)

Sektor 5 : Industri Barang Konsumsi (Consumer Goods Industry)

Masing-masing kelompok akan dianalisis lebih mendalam lagi dengan melihat apakah rasiorasio efisiensi yang didekomposisikan dari rasio ROIC berbeda. Berikut adalah gambaran statistik kelompok SCA dan UCA pada Tabel 3.

Dari tabel di atas dapat terlihat bahwa ratarata nilai ROIC (ROIC_n) perusahaan kelompok SCA lebih tinggi dibandingkan rata-rata ROIC kelompok UCA. Demikian halnya dengan nilai total aset (TA) kelompok SCA cenderung lebih tinggi dibandingkan kelompok UCA. Rasio perputaran piutang (ART), perputaran utang (APT), perputaran persediaan (INT), dan pajak terhadap penjualan (TAX_S) kelompok perusahaan SCA juga lebih tinggi dibandingkan kelompok UCA. Hal ini selaras dengan penelitian Tang dan Liou (2010) yang menyatakan bahwa perusahaan yang dapat mengelola hubungan dengan pelanggan, pemasok, maupun pemerintah akan mencapai keunggulan kompetitifnya.

Rasio harga pokok produksi terhadap penjualan (CGS_S) pada kelompok perusahaan SCA cenderung lebih rendah dibandingkan kelompok perusahaan UCA. Hal ini mengindikasikan bahwa perusahaan SCA dapat melakukan efisiensi terkait dengan pengelolaan hubungan dengan para pemasok. Nilai perputaran aset tetap (FAT) dan rasio beban penyusutan terhadap penjualan (DEP_S) kelompok SCA lebih rendah dibanding- kan kelompok perusahaan UCA, hal ini mengindikasikan kelompok perusahaan SCA mempunyai kompetensi tinggi dalam pengelolaan aset tetap.

Rasio beban iklan dan promosi terhadap penjualan (ADV_S) dan rasio beban penjualan, umum, dan administrasi terhadap penjualan pada kelompok perusahaan SCA lebih rendah dibandingkan dengan dengan kelompok UCA. Hal ini menunjukkan masih lemahnya pengelolaan aset pengetahuan perusahaan SCA. Pada kasus ini rasio beban iklan dan promosi terhadap penjualan juga dapat diproksikan sebagai pengelolaan aset pengetahuan sebagaimana dalam penelitian Kotha and Nair (1995).

Berdasarkan data tersebut, peneliti akan melakukan pengujian lebih lanjut terkait dengan karakteristik sub sampel dengan melakukan uji t sampel bebas. Hasil pengujian dapat dilihat pada Tabel 4.

Dari tabel di atas terlihat bahwa nilai ROIC (ROIC_n) untuk kedua sub sampel secara signifikan berbeda (pada $\alpha=0,05$ ) dengan nilai $t$ dan signifikansi masing-masing 2,093 dan 0,038. Hasil ini menunjukkan bahwa kedua kelompok secara statistik mempunyai perbedaan dalam karakteristik keunggulan kompetitifnya. Nilai total aset (TA) di antara ke dua kelompok tidak menunjukkan perbedaan, sehingga dapat dikatakan bahwa ke duanya dapat diperbandingkan. Berdasarkan hal tersebut, maka ke dua kelompok dapat dianalisis lebih lanjut untuk pengujian hipotesis 1 dan 2.

Untuk meninjau lebih lanjut karakteristik ke dua kelompok ini maka akan dilihat dari dekomposisi ROIC ke dalam beberapa rasio. Dari 9 rasio, hanya 3 rasio yang menunjukkan adanya perbedaan signifikan, yaitu rasio harga pokok produksi terhadap penjualan (CGS_S) dengan nilai signifikansi 0,005 ; biaya penjualan, umum, dan administrasi terhadap penjualan (SGA_S) dengan nilai signifikansi 0,017 , dan rasio biaya pajak terhadap penjualan (TAX_S) dengan nilai signifikansi 0,002. Hasil ini menunjukkan bahwa kedua kelompok mempunyai perbedaan signifikan dalam hubungannya dengan pemasok yang diproksikan dengan CGS_S, pengelolaan aset pengetahuan (SGA_S) dan hubungan dengan pemerintah (TAX_S). Nilai negatif pada proksi CGS_S dan SGA_S menunjukkan adanya korelasi negatif antara rasio tersebut dengan keunggulan kompetitif, yaitu perusahaan SCA akan cenderung mempunyai unit kos yang lebih rendah pada kedua rasio dibandingkan dengan UCA. 
Tabel 3. Karakteristik Kelompok SCA dan UCA

\begin{tabular}{lrrrrr}
\hline & ROIC_d & \multicolumn{1}{c}{ N } & Mean & Std. Deviation & Std. Error Mean \\
\hline ROIC_n & 1.00 & 72 & .4153 & .78323 & .09230 \\
& .00 & 111 & -.1722 & 2.29508 & .21784 \\
TA & 1.00 & 72 & $6.7251 \mathrm{E} 6$ & $1.14062 \mathrm{E} 7$ & $1.34423 \mathrm{E} 6$ \\
& .00 & 111 & $3.6304 \mathrm{E} 6$ & $1.79135 \mathrm{E} 7$ & $1.70027 \mathrm{E} 6$ \\
ART & 1.00 & 72 & 17.8321 & 30.70225 & 3.61829 \\
& .00 & 111 & 13.6943 & 47.87132 & 4.54374 \\
CGS_S & 1.00 & 72 & .7022 & .18697 & .02203 \\
& .00 & 111 & 1.1309 & 1.56967 & .14899 \\
APT & 1.00 & 72 & 27.2693 & 71.89945 & 8.47343 \\
& .00 & 111 & 16.7701 & 24.03267 & 2.28108 \\
INT & 1.00 & 72 & 9.5861 & 15.26380 & 1.79886 \\
& .00 & 111 & 9.0959 & 25.81603 & 2.45035 \\
SGA_S & 1.00 & 72 & .1356 & .10173 & .01199 \\
& .00 & 111 & .2044 & .27230 & .02585 \\
DEP_S & 1.00 & 72 & .0258 & .01941 & .00229 \\
& .00 & 111 & .1773 & 1.13063 & .10731 \\
FAT & 1.00 & 72 & 8.7931 & 24.10625 & 2.84095 \\
& .00 & 111 & 17.5080 & 87.50689 & 8.30579 \\
TAX_S & 1.00 & 72 & .0357 & .02583 & .00304 \\
ADV_S & .00 & 111 & .0212 & .03726 & .00354 \\
& 1.00 & 72 & .0314 & .04074 & .00480 \\
\hline
\end{tabular}

Sumber: Output diolah dengan SPSS (2013)

Keterangan:

ROIC_d : ROIC dummy (1 untuk kelompok SCA, 0 untuk kelompok UCA)

ROIC_n : Nilai ROIC

TA : Total aset (Total Assets)

ART : Rasio perputaran piutang (Account Receivable Turnover)

CGS_S : Rasio harga pokok produksi terhadap penjualan (Cost of Good Sold/Sales)

APT : Rasio perputaran utang (Account Payable Turnover)

INT : Rasio perputaran persediaan (Inventory Turnover)

SGA_S : Rasio beban penjualan, umum, dan administrasi terhadap penjualan (Sales, General, and Administration Expense/Sales)

Dep_S : Rasio beban penyusutan terhadap penjualan (Depreciation Expense/Sales)

FAT : Rasio perputaran aset tetap (Fixed Asset Turnover)

TAX_S : Rasio beban pajak terhadap penjualan (Tax Expense/Sales)

ADV_S : Rasio beban iklan dan promosi terhadap penjualan (Advertising Expense/Sales)

Tabel 4. Hasil Uji t Sampel Bebas (Independent Sample t-test) Rasio-rasio Dekomposisi ROIC

\begin{tabular}{lcccc}
\hline & Levene's Test Equality of Variances & \multicolumn{2}{c}{ t-test for Equality of Means } \\
\hline & $\mathbf{F}$ & Sig. & $\mathbf{t}$ & Sig.(2-tailed) \\
ROIC_n & 0,531 & 0,467 & 2,093 & 0,038 \\
TA & 1,422 & 0,235 & 1,304 & 0,194 \\
ART & 0,145 & 0,704 & 0,651 & 0,516 \\
CGS_S & 0,006 & $-2,846$ & 0,005 \\
APT & 7,818 & 0,056 & 1,423 & 0,157 \\
INT & 3,705 & 0,602 & 0,145 & 0,885 \\
SGA_S & 0,273 & 0,033 & $-2,417$ & 0,017 \\
DEP_S & 4,592 & 0,067 & $-1,136$ & 0,258 \\
FAT & 3,399 & 0,078 & $-0,824$ & 0,411 \\
TAX_S & 3,146 & 0,832 & 3,112 & 0,002 \\
ADV_S & 0,045 & 0,012 & $-1,137$ & 0,257 \\
\hline
\end{tabular}

Sumber: Output diolah dengan SPSS (2013)

Walaupun secara statistik nilai ROIC di antara kedua kelompok berbeda, nilai dekomposisi ROIC ke dalam rasio-rasio tidak sepenuhnya berbeda, hanya terdapat 3 rasio berbeda secara signifikan dari 9 rasio yang diuji. Hasil ini dimungkinkan karena jumlah sampel maupun tahun observasi yang singkat. Namun, peneliti tetap mengacu pada perbedaan nilai ROIC dan 
kesamaan karakteristik total aset di antara kedua kelompok dengan merujuk pada pernyataan Rumelt (1984) bahwa kumpulan sumber daya keuangan (financial resource bundles) dalam hal ini ROIC dapat digunakan untuk membedakan antara kelompok perusahaan SCA dan UCA dalam konteks konfigurasi aset yang dimilikinya. Pendapat serupa juga dinyatakan oleh Hoopes, Madsen, dan Walker (2003) serta dalam beberapa kasus bisnis oleh Ghemawat (2004) dan Ghemawat dan Nueno (2006) dalam Tang dan Liou (2010) yaitu dengan menggunakan indikator keuangan yang dikemas dalam rasio ROIC menunjukkan adanya hubungan antara kelompok sumber daya (resource bundles), penciptaan nilai, kinerja, dan pencapaian keunggulan kompetitif.

\section{Hasil Uji t Sampel Bebas}

Setelah sampel terbagi menjadi 2 kelompok, yaitu SCA dan UCA, maka langkah berikutnya adalah melakukan pengujian independen sample $t$ test untuk mengetahui lebih jauh apakah terdapat perbedaan signifikan dalam efisiensi IC. Hasil pengujian independent sample t-test dapat dilihat pada Tabel 5 .

Dari tabel di atas terlihat bahwa rata-rata nilai VAICTM untuk kelompok perusahaan SCA lebih tinggi $(5,9578)$ dibandingkan kelompok UCA (3,1144). Hasil ini menunjukkan bahwa penciptaan nilai (value creation) pada perusahaan SCA lebih tinggi dibandingkan perusahaan UCA. Hasil ini juga didukung dengan komponen-komponen pembentuk VAICTM, yaitu HCE, SCE, dan CEE yang masing-masing pada perusahaan SCA mempunyai nilai rata-rata lebih tinggi dibandingkan dengan perusahaan UCA. Demikian halnya dengan efisiensi IC yang ditunjukkan oleh nilai ICE, rata-rata nilai ICE lebih tinggi pada perusahaan SCA $(5,6721)$ dibandingkan perusahaan
UCA (2,9309). Hasil ini mendukung penelitian yang dilakukan oleh Tang dan Liou (2010), Kamukama, et al. (2010), serta Lin dan Huang (2011) yang menyatakan bahwa perusahaan yang mempunyai keunggulan kompetitif lebih efisien dalam menciptakan nilai tambah. Hasil ini juga mendukung teori RBT yang menyatakan bahwa perusahaan yang mempunyai keunggulan kompetitif berkelanjutan adalah perusahaan yang mampu menciptakan nilai tambah dari sumber dayanya (dalam hal ini diproksikan dengan VAICTM). Selain itu, perusahaan yang mempunyai keunggulan kompetitif berkelanjutan juga mempunyai karakteristik kepemilikan atas sumber daya yang bersifat VRIN dan mampu mengelolanya secara efisien (dalam hal ini ditunjukkan dengan ICE). Dengan demikian, hasil pengujian ini mendukung konsistensi teori RBT (Barney, 2001; Barney, et al., 2007).

Hipotesis 1 dan 2 diuji dengan menggunakan uji t sampel bebas, dengan hasil pengujian dapat dilihat pada Tabel 6 .

Hasil uji $\mathrm{t}$ menunjukkan bahwa terdapat perbedaan yang signifikan, baik pada nilai VAICTM maupun pada komponennya, yaitu HCE, SCE, maupun CEE. Demikian halnya dengan nilai ICE, yang signifikan berbeda di antara kedua kelompok. Hasil ini menunjukkan bahwa perusahaan yang mempunyai keunggulan kompetitif berkelanjutan (SCA) mempunyai kemampuan dalam menciptakan nilai tambah maupun mengelola aset intelektualnya; yang lebih tinggi dibandingkan perusahaan yang mempunyai keunggulan kompetitif takberkelanjutan (UCA). Hasil ini selain mendukung penelitian yang dilakukan oleh Tang and Liou (2010), Kamukama, et al. (2010), dan Lin and Huang (2011), juga mendukung teori RBT yang dikemukan oleh Barney (2001) dan Barney and Clark (2007). Dengan demikian, hipotesis 1 dan 2 terdukung.

Tabel 5. Statistik Deskriptif Nilai VAIC, HCE, SCE, ICE, CEE

\begin{tabular}{cccccc}
\hline Variabel & Sub sampel & $\mathbf{N}$ & Mean & Std.Deviation & Std. Error Mean \\
\hline VAICTM & 1 & 72 & 5,9578 & 2,71770 & 0,32028 \\
& 0 & 111 & 3,1144 & 4,01234 & 0,38083 \\
HCE & 1 & 72 & 4,9363 & 2,57430 & 0,30338 \\
& 0 & 111 & 2,5618 & 3,78849 & 0,35959 \\
SCE & 1 & 72 & 0,7358 & 0,14205 & 0,01674 \\
& 0 & 111 & 0,3691 & 0,65862 & 0,06251 \\
ICE & 1 & 72 & 5,6721 & 2,69438 & 0,31754 \\
& 0 & 111 & 2,9309 & 4,00357 & 0,38000 \\
CEE & 1 & 72 & 0,2847 & 0,19452 & 0,02292 \\
& 0 & 111 & 0,1839 & 0,28444 & 0,02700 \\
\hline
\end{tabular}

Sumber: Output diolah dengan SPSS (2013)

Keterangan:

Sub sampel 1: Kelompok SCA

Sub sampel 0: Kelompok UCA 
Tabel 6. Hasil Uji t Sampel Bebas

\begin{tabular}{lcccc}
\hline & \multicolumn{2}{c}{ Levene's Test Equality of Variances } & \multicolumn{2}{c}{ t-test for Equality of Means } \\
\cline { 2 - 5 } & F & Sig. & t & Sig.(2-tailed) \\
\hline VAICTM & 0,003 & 0,955 & 5,277 & 0,000 \\
HCE & 0,032 & 0,858 & 4,663 & 0,000 \\
SCE & 27,479 & 0,000 & 5,667 & 0,000 \\
ICE & 0,013 & 0,908 & 5,106 & 0,000 \\
CEE & 0,284 & 0,595 & 2,634 & 0,009 \\
\hline
\end{tabular}

Sumber: Output diolah dengan SPSS (2013)

\section{Pembahasan}

Hipotesis 1 yang menyatakan bahwa terdapat perbedaan penciptaan nilai tambah yang diproksikan dengan VAIC ${ }^{\mathrm{TM}}$ antara perusahaan SCA dan UCA didukung oleh data penelitian atau hipotesis 1 terdukung. Nilai VAICTM pada perusahaan SCA menunjukkan rata-rata yang lebih tinggi yaitu 5,9578 dibandingkan dengan perusahaan UCA, yaitu 3, 1144. Hasil ini mendukung penelitian yang dilakukan oleh Tang and Liou (2010) serta Lin and Huang (2011). Penelitian Tang and Liou (2010) menunjukkan adanya perbedaan dalam rasio-rasio dekomposisi ROIC antara perusahaan dengan keunggulan kompetitif dan perusahaan dengan kerugian bersaing (competitive disadvantage), terutama dalam pengelolaan pengetahuan (knowledge management). Perusahaan dengan keunggulan kompetitif cenderung untuk melakukan pengelolaan pengetahuan karyawan yang tercermin dari intensitas intellectual property yang dimiliki, sebaliknya perusahaan dengan kerugian bersaing cenderung untuk tidak mengoptimalkan pengelolaan pengetahuan karyawan.

Hasil penelitian ini juga mendukung penelitian yang dilakukan oleh Lin and Huang (2011) yang membedakan antara perusahaan yang sarat dengan aset takberwujud dengan yang tidak. Perusahaan dengan intensitas aset takberwujud yang tinggi memiliki kinerja superior yang tinggi pula $^{3}$, demikian halnya dengan respons investor. Investor merespon lebih baik (diukur dengan abnormal return) pada perusahaan yang sarat aset takberwujud karena mempunyai prospek masa depan yang lebih baik dan mampu mempertahankan keunggulannya dengan terus melakukan inovasi. Demikian halnya dengan penelitian Kamukama, et al. (2010) yang menunjukkan hasil bahwa keunggulan kompetitif menjadi mediator antara efisiensi IC dan kinerja perusahaan, serta penelitian Chang (2010) yang menunjukkan

\footnotetext{
3 Penelitian Lin and Huang (2011) menggunakan istilah keunggulan kompetitif dan kinerja superior secara bergantian dan memaknainya sebagai suatu konsep yang dapat saling menggantikan.
}

adanya perbedaan nilai VAIC ${ }^{\text {TM }}$ antara perusahaan IT dan non-IT di Taiwan.

Berdasarkan pembahasan di atas maka dapat disimpulkan bahwa perusahaan yang mampu mengelola kapital (aset) dengan baik, termasuk aset intelektualnya atau IC dapat mempertahankan keunggulan kompetitifnya. IC sebagai aset unik yang bersifat VRIN dapat menjadi alat untuk memenangkan persaingan sebagaimana dinyatakan dalam teori RBT (Barney 2001, Barney and Clark 2007).

Komponen VAICTM didekomposisikan pada hipotesis 2 untuk melihat lebih jauh apakah terdapat perbedaan komponen VAICTM (HCE, SCE, CEE) maupun efisiensi IC (ICE) antara kelompok perusahaan SCA dan kelompok perusahaan UCA. Terdapat perbedaan signifikan HCE, SCE, dan CEE pada kedua kelompok tersebut. Rata-rata nilai HCE, SCE, dan CEE pada kelompok perusahaan SCA cenderung lebih tinggi. Demikian halnya dengan efisiensi IC yang diproksikan dengan nilai ICE pada dua kelompok yang diujikan mempunyai nilai yang secara signifikan berbeda. Hal ini mengindikasikan bahwa perusahaan yang mampu mempertahankan keunggulan kompetitifnya akan memberikan nilai tambah melalui pengelolaan IC dan sumber daya fisis maupun finansial lebih tinggi dibandingkan dengan perusahaan yang tidak mampu mempertahankan keunggulan kompetitifnya. Nilai tambah yang direspon oleh pemangku kepentingan akan memberikan posisi yang menguntungkan bagi perusahaan untuk terus berinovasi dan bersaing dalam bisnis (Barney, et al. 2001, Pulic 2010, Roslender and Fincham 2001, Widener 2007, Barney and Clark 2007).

Penelitian ini secara implisit mendukung penelitian yang dilakukan oleh Chang (2010), bahwa perusahaan memberikan porsi yang berbeda dalam pengelolaan komponen VAICTM. Perusahaan IT yang cenderung lebih mengutamakan dalam inovasi produk akan memiliki nilai HCE yang lebih tinggi, namun demikian, jika tidak didukung dengan infrastruktur dan sistem informasi yang memadai (SCE dan CEE) maka justru akan mengurangi profitabilitas perusahaan. Berdasarkan hasil penelitian Chang (2010) maka 
dapat diperoleh interpretasi atas hasil penelitian ini bahwa perusahaan yang mempunyai keunggulan kompetitif berkelanjutan cenderung mengelola sumber daya atau asetnya dengan baik, terbukti dari komponen-komponen HCE, SCE, maupun CEE yang mempunyai nilai lebih tinggi dibandingkan perusahaan yang mempunyai keunggulan kompetitif takberkelanjutan. Pemanfaatan IC pada kelompok perusahaan SCA juga dapat dikatakan lebih efisien dibandingkan kelompok perusahaan UCA. Efisiensi dalam IC (ICE) dan kapital fisis dan finansial (CEE) merupakan faktor utama agar perusahaan mampu memberikan nilai tambah sehingga berkontribusi pada posisi persaingan yang menguntungkan dan tentu saja berdampak positif pada kinerja perusahaan secara keseluruhan.

\section{KESIMPULAN DAN SARAN}

Penelitian ini bertujuan untuk mengetahui apakah efisiensi IC berkontribusi dalam membentuk keunggulan kompetitif berkelanjutan sebagaimana dinyatakan dalam RBT. Pengujian secara empiris dilakukan dengan melakukan analisis komparasi di antara kelompok perusahaan dengan keunggulan kompetitif berkelanjutan dan takberkelanjutan. Berdasarkan hasil pengujian dan analisis statistik serta interpretasi atas hasil pengujian, diperoleh kesimpulan bahwa kelompok perusahaan yang mampu mempertahankan keunggulan kompetitifnya mempunyai kemampuan dalam memberikan nilai tambah bagi pemangku kepentingan, yang ditandai dengan tingginya nilai VAICTM, selain itu perusahaan jenis ini juga mampu mengelola aset intelektualnya secara efisien dibandingkan dengan perusahaan yang tidak dapat mempertahankan keunggulan kompetitifnya. Hasil pengujian empiris mendukung teori RBT yang menyatakan bahwa penciptaan keunggulan kompetitif dapat dilakukan melalui pemanfaatan sumber daya yang bersifat VRIN untuk menciptakan nilai tambah bagi stakeholder.

Penelitian ini tentu saja tidak lepas dari kekurangan. Berikut adalah beberapa keterbatasan penelitian ini:

1. Sampel yang digunakan adalah perusahaan yang masuk dalam secondary sector versi JASICA, dan hanya pada kode sektor 4 dan 5 saja, sehingga hasil penelitian tidak dapat digeneralisasi untuk populasi penelitian.

2. Penggunaan data sekunder dan data pasar modal mengandung kelemahan tidak tertangkapnya fenomena IC secara utuh sebagaimana argumentasi Bontis (1998), Bontis, et al. (1999, 2000).
3. Penggunaan tahun pengamatan yang sangat singkat dapat mengurangi kekuatan argumenttasi maupun generalisasi atas hasil penelitian, terutama dalam penggunaan proksi atas keunggulan kompetitif yang berkelanjutan.

Berdasarkan keterbatasan penelitian tersebut, maka penelitian selanjutnya hendaknya memperluas sampel penelitian tidak terbatas pada satu sektor saja, dikarenakan ada kemungkinan perbedaan pola pengelolaan IC yang berbeda untuk sektor berbeda (Widener 2006). Kriteria keunggulan kompetitif berkelanjutan hendaknya lebih diperdalam lagi mengingat keunggulan kompetitif berkelanjutan tidak hanya ditandai dengan jangka waktu yang panjang, namun juga kemampuan pesaing dalam melakukan duplikasi atas sumber daya stratejik (Barney and Clark 2007).

\section{DAFTAR PUSTAKA}

Andriessen, D. (2004). Making Sense of Intellectual Capital: Designing a Method for the Valuation of Intangibles. Oxford: Elsevier Butterworth.

Barney, J. B. (1991). Firm Resources and Sustained Competitive Advantage. Journal of Management, 17, 99-120.

Barney, J. B. and Arikan. (2001). The Resourcebased View: Origins and Implications. Strategic Management Journal, 716, 124-188.

Barney, J. B. and Clark, D. N. (2007). Resource-based Theory: Creating and Sustaining Competitive Advantage. New York: Oxford University Press, Inc.

Barney, J. B., Wright, M., and Ketchen, D. J. 2001. The Resource-based View of The Firm: Ten Years After 1991. Journal of Management, 27, 625-641.

Bisbe, J. and Otley, D. (2004). The Effects of the Interactive Use of Management Control Systems on Product Innovation. Accounting, Organizations, and Society, 29, 709-737.

Bontis, N. (1998). Intellectual Capital: An Exploratory Study that Develops Measures and Models. Management Decisions, 36(2), 63-76.

Bontis, N. (1999). Managing Organizational Knowledge by Diagnosing Intellectual Capital; Framing and Advancing The State of The Field. International Journal of Technology Management. 18, Nos. 5/6/7/8, 433-463.

Bontis, N., Keow, W. C., and Richardson, S. (2000). Intellectual Capital and Business Performance in Malaysian Industries. Journal of Intellectual Capital, 1(1), 85-100. 
Bozzolan, S., O'Regan, P., and Ricerri, F. (2006). Intellectual Capital Disclosure (ICD): A Comparasion of Italy and the UK. Journal of Human Resource Costing and Accounting, 10(2), 92-113.

Brooking, A. (1997). The Management Intellectual Capital. Long Range Planning, 30, 364-365.

Chang, W. (2010). The Different Proportion of IC Components and Firms' Market Performance: Evidence from Taiwan. The International Journal of Business and Finance Research, 4(4), 121-134.

Cheng, M., Lin, J., Hsiao, T., and Lin, T. W. (2010). Invested Resource, Competitive Intellectual Capital, and Corporate Performance. Journal of Intellectual Capital, 11(4), 433-450.

Choudhury, J. (2010). Performance Impact of Intellectual Capital: A Study of Indian IT Sector. International Journal of Business and Management, 5(9), 72-80.

Connelly, C. E., Zweig, D., Webster, J., and Trougakos, J. (2012). Knowledge Hiding in Organizations. Journal of Organizational Behavior, 33, 64-88.

Dunamis. (2013). Succesful Implementation of KM in Indonesia. PT. Dunamis Intra Sarana, Jakarta.

Firer, S. and Williams, S. M. (2003). Intellectual Capital and Traditional Measures of Corporate Performance. Journal of Intellectual Capital, 4(3), 348-360.

Gates, S. and Langevin, P. (2010). Human Capital Measures, Strategy and Performance: HR Managers' Perceptions. Accounting, Auditing \& Accountability Journal, 23(1), 111-132.

Guthrie, J., Ricceri, F., and Dumay, J. (2012). Reflections and Projections: A Decade of Intellectual Capital Accounting Research. The British Accounting Review, 44, 68-82.

Henri, J. (2006). Management Control Systems and Strategy: A Resource-based Perspective. Accounting, Organizations, and Society, 31, 529-558.

Hoopes, D. G., Madsen, T. L., and Walker, G. (2003). Guest editors's introduction to the special issue: why is there a resource-based view? Toward a theory of competitive heterogeneity. Strategic Management Journal, 24, 889-902.

Kamukama, N., Ahiauzu, A., and Ntayi, J. M. (2011). Competitive Advantage: Mediator of Intellectual Capital and Performance. Journal of Intellectual Capital, 12(1), 152-164.

Khani, A., Ahmadi, F., and Homayouni, G. (2011). The Impact of Intellectual Capital on Per- formance of Iranian Food Firms. Interdiciplinary Journal of Contemporary Research in Business, 2(10), 315-326.

Kotha, S. and Nail, A. (1995). Strategy and Environment as Determinants of Performance: Evidence from the Japanese Mechine Tool Industry. Strategic Management Journal, 16, 497-518.

Lev, B. and Zarowin, P. (1999). The Boundaries of Financial Reporting and How to Extend Them. Journal of Accounting Research (Autumn), 252-285.

Lin, C. and Huang, C. (2011). Measuring Competitive Advantage with an Asset-Light Valuation Model. African Journal of Business Management, 5(13), 5100-5108.

Margaretha, F. and Rahman, A. (2006). Analisis Pengaruh Intellectual Capital terhadap Market Value dan Fianancial Performance Perusahaan dengan Metode Value Added Intellectual Coefficient. Jurnal Bisnis dan Akuntansi, 8(2), 199-217.

Peteraf, M A. (1993). The Cornerstones of Competitive Advantage: A Resource-based View. Strategic Management Journal, 14(3), 179-191.

Petty, R. and Guthrie, J. (2000). Intellectual Capital Literature Review: Measurement, Reporting, and Management. Journal of Intellectual Capital, 1(1), 155-176.

Porter, M. E. (1985). Competitive Advantage: Creating and Sustaining Superior Performance. New York: Free Press.

Pulic, A. An Accounting Tool for IC Management. www.measuring-ip.at/Papers/ham99txt.htm. accessed 2010.

Pulic, A. (2004). Intellectual Capital-Does it Create of Destroy Value? Measuring Business Excellence, 8(1), 62-68.

Ray, G., Barney, J. B., and Muhana, W. A. (2004). Capabilities, Business Process, and Competitive Advantage: Choosing The Dependent Variable in Empirical Test of The Resourcebased View. Strategic Management Journal, 25, 23-37.

Roberts, P. W. (1999). Product Innovation, ProductMarket Competition and Persistent Profitability in the U.S Pharmaceutical Industry. Strategic Management Journal, 20, 655-670.

Roos, G. and Roos, J. (1997). Measuring your Companies Intellectual Performance. Long Range Planning, 30, 413-426.

Roslender, R. and Fincham, R. (2001). "Thinking Critically about Intellectual Capital Accounting." Accounting, Auditing, and Accountability Journal, 14(4), 383-398. 
Rumelt, R. P. (1984). Towards a strategic theory of the firm. In Competitive Strategic Management. Lamb RB (ed). Prentice-Hall, 556-570.

Schroeder, R. G., Bates, K. A. and Junttila, M. A. (2002). A Resource-based View of Manufacturing Strategy and the Relationship to Manufacturing Performance. Strategic Management Journal, 23, 101-117.

Shiu, H. (2006). The Application of The Value Added Intellectual Coefficient to Measure Corporate Performance: Evidence from Technological Firms. International Journal of Management, 23(2), 356-365.

Singh, I. and Zahn, J. L. W. (2008). Determinants of Intellectual Capital Disclosure in Prospectuses of Initial Public Offerings. Accounting and Business Research, 38(5), 409-431.

Skinner, D. J. (2008). Accounting for Intangibles- A Critical Review of Policy Recommendations. Accounting and Business Research, 38(3), 191204.

Spanos, Y. E. and Lioukas, S. (2001). An Examination into the Causal Logic of Rent Generation: Contrasting Porter's Competitive Strategy Framework and the Resource-based View Perspective. Strategic Management Journal, 22, 907-934.
Suhardjanto, D. and Wardhani, M. (2010). Praktik Intellectual Capital Disclosure Perusahaan yang Terdaftar di Bursa Efek Indonesia. Jurnal Akuntansi dan Auditing Indonesia, 14(1), 71-85.

Suwarno, N. (Agustus 2011). Pengaruh Intellectual Capital terhadap Kinerja Keuangan dengan Ukuran, Jenis Industri, dan Leverage sebagai Variabel Moderating. Majalah Ekonomi, 2, 165-184.

Tang, Y. and Liou, F. (2010). Does Firm Performance Reveal It's Own Causes? The Role of Bayesian Inference. Strategic Management Journal, 31, 39-57.

Toms, S. (2010). Value, Profit, and Risk: Accounting and the Resource-based View of the Firm. Accounting, Auditing \& Accountability Journal, 23(5), 647-670.

Ullum, I. (April 2011). Analisis Praktik Pengungkapan Informasi Intellectual Capital dalam Laporan Tahunan Perusahaan Telekomunikasi di Indonesia. Jurnal Reviu Akuntansi dan Keuangan, 1(1), 49-55.

Widener, S. (2006). Associations between Strategic Resource Importance and Performance Measure Use: The Impact on Firm Performance. Management Accounting Research, 17, 433-457. 